\title{
Regulated discharge produces substantial demographic changes on four typical fish species of a small salmonid stream
}

\author{
Michaël Ovidio · Hervé Capra • \\ Jean-Claude Philippart
}

(C) Springer Science+Business Media B.V. and FAO 2008

\begin{abstract}
A hydroelectric power plant (HPP) started operation in December 2002 on the River Lhomme, (mean annual flow: $1.78 \mathrm{~m}^{3} \mathrm{~s}^{-1}$; mean annual water temperature: $9.9^{\circ} \mathrm{C}$ ). The new HPP bypasses the river over a length of $1.2 \mathrm{~km}$. The minimum flow allowed in the bypassed section is currently fixed at $0.220 \mathrm{~m}^{3} \mathrm{~s}^{-1}$. Before the construction of the HPP, two contrasted 150-m-long reaches of the Lhomme were selected to estimate their total fish population abundance and to analyse their fish population dynamics. Electrofishing was carried out in each of these two reaches on 23 April 2002 in a natural flow situation to remove the fish. Other inventories were carried out in late April or early May in 2003, 2004, 2005 and 2006 in minimum flow conditions. The results revealed a prompt and severe decrease in the total fish biomass (up to $81 \%$ for grayling from 2002 to 2006) combined with severe changes in the fish
\end{abstract}

Guest editors: R. L. Welcomme \& G. Marmulla Hydropower, Flood Control and Water Abstraction: Implications for Fish and Fisheries

M. Ovidio $(\varangle) \cdot$ J.-C. Philippart

Biology of Behaviour Unit, Laboratory of Fish Demography and Hydroecology, University of Liège, 10 Chemin de la Justice, Tihange 4500, Belgium e-mail: m.ovidio@ulg.ac.be

H. Capra

Biologie des Ecosystemes Aquatiques, Cemagref of Lyon, 3 bis quai Chauveau CP 220, Lyon 69336, France community structure that were not observed in a reference site. The effects of the flow reduction varied considerably depending on the size of the individuals, the species concerned and their habitat availability, which was modelled using a classical physical habitat simulation (EVHA method).

Keywords Minimum flow · Fish community · Habitat modelling · Size composition .

Biomass $\cdot$ Salmonid stream

\section{Introduction}

The health of a river is partially characterised by its water discharge (Norris \& Thoms, 1999). Setting minimum flow regulations requires knowledge to determine the quantity of water, over time, to maintain the river's health in a particular state (Acreman \& Dunbar, 2004). Fish populations are affected by variable and minimum stream flows that create suboptimal conditions (changing habitat availability, nutrient cycling and food availability) that frequently lead to decreased survival during early life history stages and to the creation of physiological stresses on adult fishes (Rogers et al., 2005).

Species-specific responses to minimum flow depend on their reproduction strategy, generation time and habitat needs (Paller, 1997). European 
Inland Fisheries Advisory Commission recommends that (EIFAC, 2006) it has become necessary to better understand the potential effects of minimum and variable flows on a wide range of fish communities in different river typologies. Such knowledge is also basic to the implementation of the European Water Framework Directive (2000) in European countries. Hydropower stations have often been built as part of large dam projects. However, owing to the cost and environmental impacts of these dams, hydrodevelopments are now increasingly focused on small-scale projects undertaken for the most part by private producers (Santos et al., 2006). Ecological information is not readily available on the impacts of these micro-power plants (production $<10$ MW year ${ }^{-1}$ ) on fish communities. In Europe, most studies have investigated brown trout (Salmo trutta (L.)) in the upper part of small streams (Baran et al., 1995; Gouraud et al., 1999, 2001; Capra et al., 2003).

The impact of flow regulation has rarely been considered in the grayling zone of salmonid streams, where the brown trout and the European grayling (Thymallus thymallus (L.)) live in sympatry and are the dominant fish species (Gibbins \& Heslop, 1998). The European grayling is still classified as a highly vulnerable fish species (Appendix III, Bern Convention, Council of Europe, 1979) and its biotopes have been severely damaged by human activities since the early nineteenth century (Philippart \& Vranken, 1983; Northcote, 1995; Mallet et al., 2000). Currently, since hydropower production will probably increase its distribution area in the coming years, there is an urgent need to better understand the sensitivity of the species to minimum flow conditions and to compare its responses with those of brown trout and small-bodied accompanying species (bullhead and stone loach). This was the aim of our study conducted over five consecutive years in a small stream in the Belgian Ardennes, before and after the installation of a new micro-hydroelectric power plant. Evaluations combined habitat modelling analysis and biological surveys to assess the role of habitat changes on the modifications in the fish population dynamics. Analyses were performed by putting special emphasis on the most representative species of the stream, the brown trout, the European grayling and, to a lesser extent, the bullhead and the stone loach.

\section{Study site}

The River Lhomme

The study was conducted in the Lhomme, a tributary of the Lesse in the River Meuse basin (Fig. 1). According to the invertebrate's population, the water quality of the Lhomme is good (VandenBosshe, 2005). The stream slope in the study section is $10 \%$ o and the fish assemblage is typical of the grayling zone (Huet, 1949). The mean daily temperature ranges from 0.6 to $21.4^{\circ} \mathrm{C}$ and the mean annual temperature is $9.9^{\circ} \mathrm{C}$ (data from the University of Liège recorded from February 2002 to February 2006, Tidbit Onset temperature data loggers). The substrate is typical of a gravel bed river. In natural flow conditions, the mean annual flow in the study site was $1.78 \mathrm{~m}^{3} \mathrm{~s}^{-1}$ (data from 1994 to 2002, gauging station of the DGRNE Water-Division) and the median flow $\left(\mathrm{Q}_{50}\right)$ was $1.15 \mathrm{~m}^{3} \mathrm{~s}^{-1}$. The maximum historical flow recorded was $22.68 \mathrm{~m}^{3} \mathrm{~s}^{-1}$. The mean drought level flow during summer is $0.5 \mathrm{~m}^{3} \mathrm{~s}^{-1}$. The width of the river in the studied area varied from 7 to $13 \mathrm{~m}$ depending on flow conditions.

In this part of the river, the fish population of the Lhomme is essentially composed of brown trout, European grayling, stone loach (Barbatula barbatula (L.)), bullhead (Cottus rhenanus, formerly Cottus gobio (Freyhof et al., 2005)), eel (Anguilla Anguilla (L.)) and less abundant accompanying species, European minnow (Phoxinus phoxinus (L.)), river lamprey (Lampetra planeri (Bloch)). Some sporadic species such as northern pike (Esox lucius (L.)), roach (Rutilus rutilus (L.)), chub (Leuciscus cephalus (L.)) and the tench (Tinca tinca (L.)) probably originated from fish farming pond close to the study site.

The hydroelectric power plant (HPP)

The HPP (Fig. 1C) started operation in December 2002 and is expected to produce $900,000 \mathrm{~kW}$ per year. This HPP is located downstream of four other HPPs in the main course of the river Lhomme. The new HPP bypasses the river over a length of $1.2 \mathrm{~km}$ and is configured as presented in Fig. 1C. The minimum flow allowed in the bypass section is currently fixed at $0.220 \mathrm{~m}^{3} \mathrm{~s}^{-1}$ by the regional Walloon water administration in agreement with the producer, as no standardised rule on the setting of 
Fig. 1 (A) Location of the study site in Belgium. (B) Location of the studied HPP and the four others HPP (C) Configuration of the HPP exploitation area and location of reach 1 , reach 2 and the reference reach in natural flow conditions

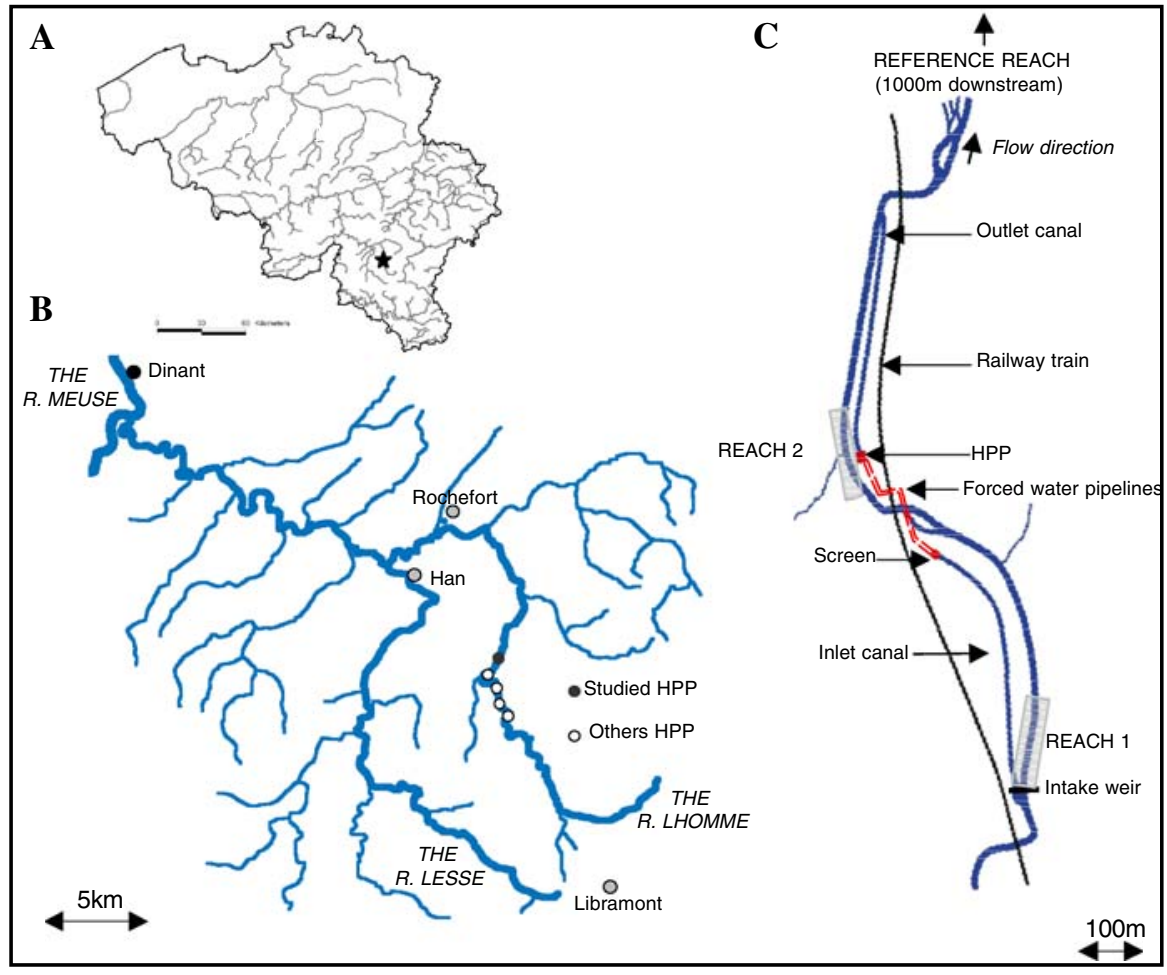

minimum flow exists at present in Belgium. Based on historical flow data, this minimum flow will increase the mean duration of the drought (low flows) from 86 to 128 days per year.

\section{Material and methods}

Habitat modelling

Habitat was described and modelled using EVHA software (Pouilly et al., 1995; Ginot et al., 1998), which is similar to the more widely used PHABSIM (Bovee, 1982) but uses the Limerinos (1970) instead of the Manning formulae to estimate bed hydraulic roughness. This allows the preservation of a fixed coefficient of friction, even at low flow, in rivers where the size of the substrate can be equivalent to the depth of water. Using preference curves for the habitat (described in terms of velocity, depth and nature of substrate), EVHA quantifies the potential carrying capacity, or WUA (weighted usable area) (Bovee, 1982; Sabaton et al., 1995; Ginot et al., 1998), for brown trout, European grayling, bullhead and stone loach for a given discharge range. The preference curves used for this study are those of Bovee (1978), adapted to French streams for brown trout (Belaud et al., 1989; Souchon et al., 1989). Preference curves for stone loach and bullhead were those of Lamouroux et al. (1999); curves for European grayling were calculated using unpublished data of the University of Liège (C. Blase, Ms thesis on grayling habitat preferences). A graphical analysis of the weighted usable area (WUA)-discharge curves for the four species estimated the sensitivity of these species to modifications in discharge in the two reaches of the Lhomme. EVHA was also employed to estimate the wetted area (WA) of the two reaches studied in relation to river flow. The estimation of the biomass per unit of wetted area (B/WA) before and after the exploitation of the HPP was compared using the values of WA during median flow $\left(1.15 \mathrm{~m}^{3} \mathrm{~s}^{-1}\right)$ and minimum flow $\left(0.220 \mathrm{~m}^{3} \mathrm{~s}^{-1}\right)$, respectively.

Changes in the fish community

Before the HPP began operating, two 150-m-long reaches of the Lhomme that were to be modified by the HPP were selected to estimate their total fish population abundance to be used as a baseline 
(location of the impacted reaches on Fig. 1C). These sections were inventoried by removal of fish by electrofishing on 23 April 2002 using intensive fishing methods: two successive passages, three generators, three electrodes and six hand nets. Inventories in bypass discharge conditions were carried out on 6 May 2003 (17 weeks after the start-up of the HPP), 21 April 2004, 10 May 2005 and 19 April 2006 using exactly the same intensive removal fishing methodology and during minimum flow conditions. Identical surveys were also performed in a natural 150-m-long section (Fig. 1C) of the Lhomme (located $1200 \mathrm{~m}$ downstream from the impacted reach) on 22 April 2004, 11 May 2005 and 20 April 2006. The site was not sampled in 2002 and 2003 for logistical reasons.

European grayling and brown trout were individually measured (fork length in millimetres) and weighted (in grams). Bullhead and stone loach were individually measured and globally weighed. These data were used to calculate the observed population biomass of each species, the distribution of the length classes as well as the observed population biomass structure (proportion of biomass of each species compared to the total biomass). As we calculated that $70.1 \%$ of brown trout biomass (or $65 \%$ of trout abundance) and $82.6 \%$ of European grayling biomass (or $81.5 \%$ of European grayling abundance) were captured during the first passage (in comparison with the total captured biomass after the two passages), we did not use a multiple-pass removal model to estimate fish population abundance during the electric fishing surveys. Moreover, demographic analysis used only the individual length and weight, i.e. without any estimation. Then, analyses were based on the sum of the captures during the two passages for each survey.

\section{Results}

Description and modelling of habitat in the impacted study reaches

Reach 1 (Fig. 1C) is located downstream of the intake weir. It is a linear riffle section characterised by an abundance of instream cover (roots and large rocks). Reach 2 (Fig. 1C) is characterised by the presence of a deep run and less instream cover. During median flow $\left(\mathrm{Q}_{50}\right)$, and the mean velocity of reaches 1 and 2 were 0.38 and $0.35 \mathrm{~ms}^{-1}$ and the average depths were $0.22 \mathrm{~m}$ and $0.30 \mathrm{~m}$, respectively. The average size of the bedrock was $0.10 \mathrm{~m}$ in reach 1 and $0.24 \mathrm{~m}$ in reach 2 . In the reference site, the mean velocity was $0.43 \mathrm{~ms}^{-1}$, the mean depth was $0.23 \mathrm{~m}$ during the median flow conditions. The average size of the bedrock in the reference site was $0.08 \mathrm{~m}$.

The wetted area of reaches 1 and 2 was similar during minimum flow conditions $\left(0.220 \mathrm{~m}^{3} \mathrm{~s}^{-1}\right)$ and was evaluated at $1350 \mathrm{~m}^{2}$ (Fig. 2). With increasing discharge, the estimation of the wetted area of reach 1 was always higher than that of reach 2. At $\mathrm{Q}_{50}$ $\left(1.15 \mathrm{~m}^{3} \mathrm{~s}^{-1}\right)$, the wetted area was evaluated as $1735 \mathrm{~m}^{2}$ in reach 1 and $1624 \mathrm{~m}^{2}$ in reach 2 .

The curves for trends in WUA as a function of discharge clearly indicate that at low flow the habitat suitability for European grayling is extremely poor in reaches 1 and 2 (Fig. 3). The curves increased almost linearly in both reaches with increases in discharge. The curves for adult brown trout in reaches 1 and 2 are different. WUA for brown trout increased with discharge, varying from 0 to $2.4 \mathrm{~m}^{3} \mathrm{~s}^{-1}$ in reach 1 and from 0 to $1.5 \mathrm{~m}^{3} \mathrm{~s}^{-1}$ in reach 2 . At low flow, WUA in reach 2 was better than in reach 1. WUA for bullhead started decreasing at $2 \mathrm{~m}^{3} \mathrm{~s}^{-1}$ in both
Fig. 2 Changes in the wetted area as a function of discharge in the impacted study reaches 1 and 2 based on habitat modelling

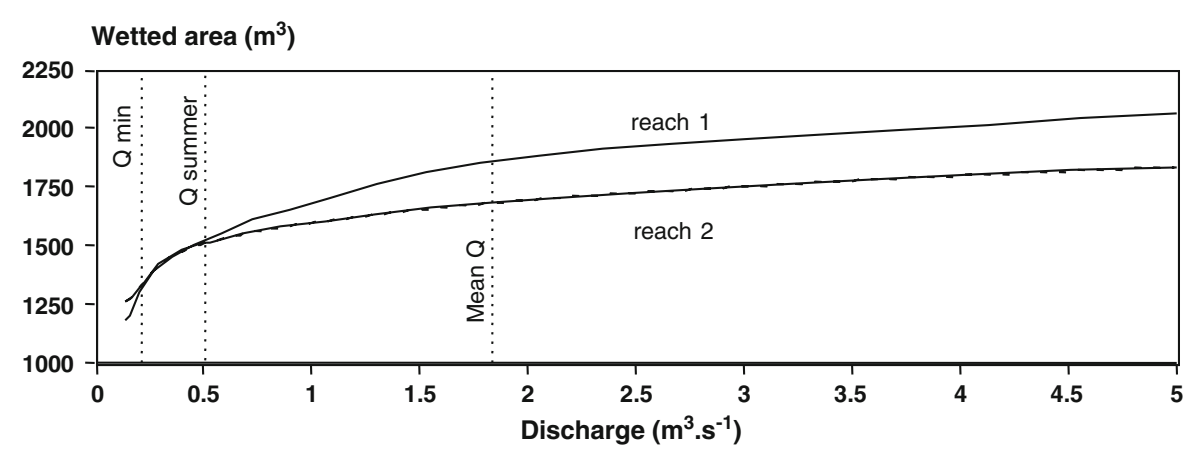


Fig. 3 Changes in the WUA as a function of discharge in the impacted study reaches 1 and 2 based on habitat modelling. The dotted line represents the minimum flow
REACH 1
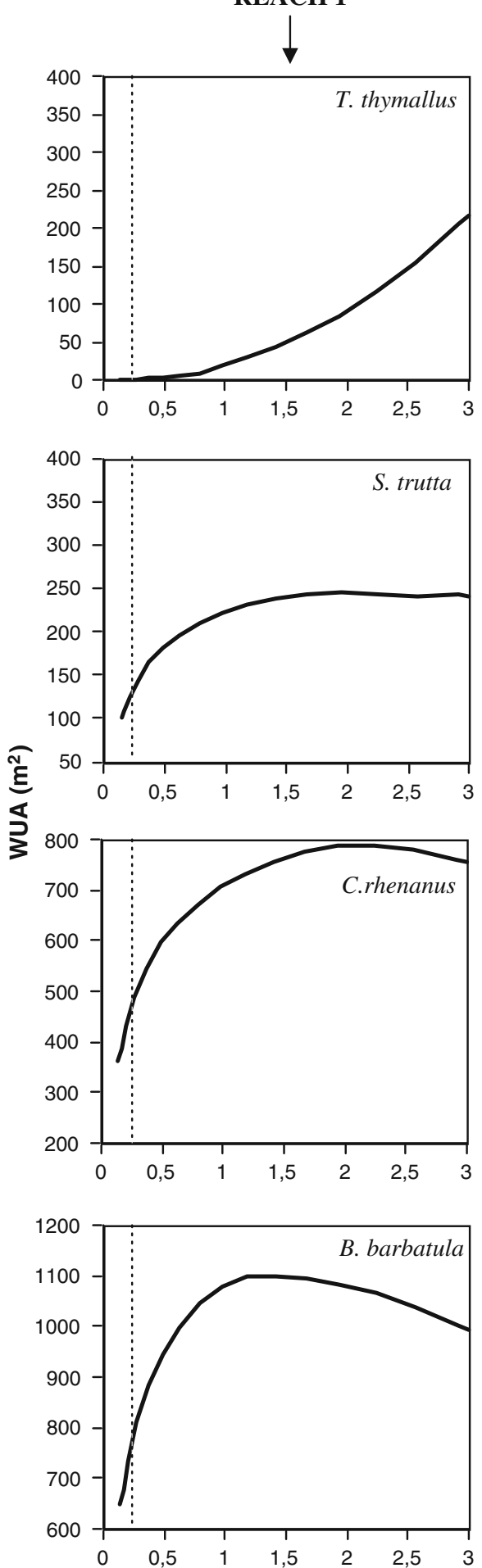

REACH 2
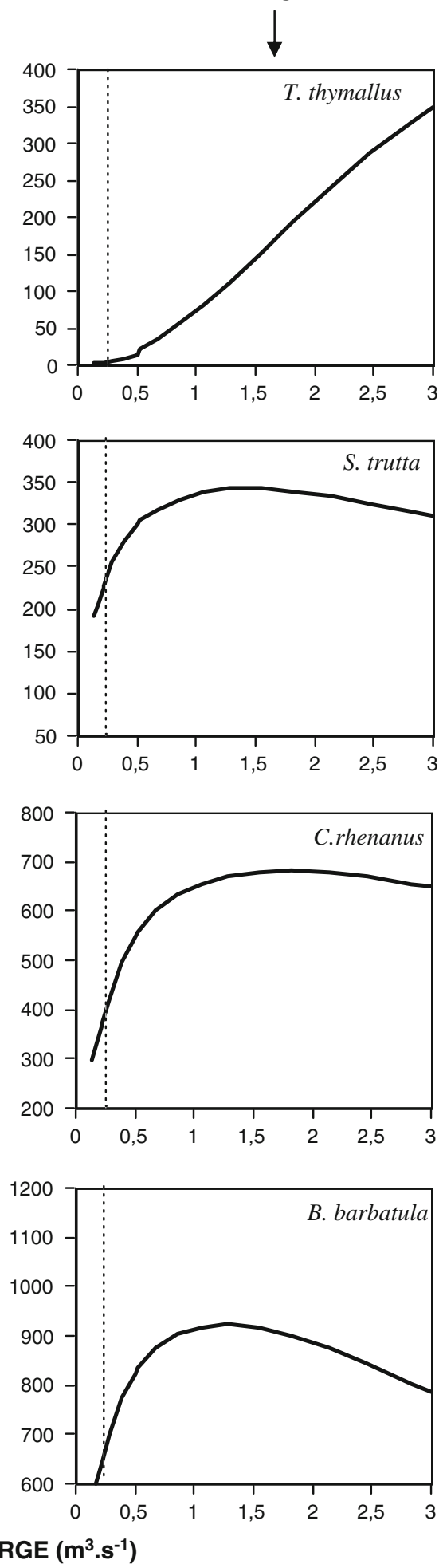
reaches, but the model showed that reach 1 was better suited in all flow conditions. WUA for stone loach started decreasing at $1.3 \mathrm{~m}^{3} \mathrm{~s}^{-1}$ in both reaches. As was the case for bullhead, WUA was always better in reach 1 . The model also suggested that at low flow, the WUA was better for small-bodied (bullhead, stone loach) than for large-bodied species (adult brown trout and European grayling).

\section{Changes in fish community biomass}

In 2002, during natural flow conditions, the fish population of both study reaches of the Lhomme was as follows. In reach $1, n=527$ individuals were captured for a total fish biomass of $15.7 \mathrm{~kg}$ (42\% brown trout, $24.6 \%$ European grayling, $8.8 \%$ bullhead, $8.9 \%$ stone loach and $15.7 \%$ other species). In the deeper reach 2, $n=391$ individuals were captured for a total fish biomass of $19.7 \mathrm{~kg}$ (43.5\% brown trout, 39.6\% European grayling, 3\% bullhead, $1.9 \%$ stone loach and $12 \%$ other species).

Only 17 weeks after the start-up of the HPP in May 2003 (after the spawning season of the European grayling in 2003), the fish population biomass of each species rapidly decreased in both reaches (Fig. 4). Changes were more substantial in reach 1 , with, for example, an $86 \%$ decline in European grayling population biomass, a $28 \%$ decrease in the brown trout population biomass and $49 \%$ and $56 \%$ decrease in the bullhead and stone loach population biomass, respectively. In 2004, the European grayling and brown trout population biomass continued to drop in both reaches, but the bullhead and stone loach populations highly increased in reach $1(+162 \%$ and $+175 \%$ in comparison with 2003) and to a lesser extent in reach 2. In 2005 and 2006, the fish biomass remained stable at values similar to those observed in 2004. In comparison with the initial situation (year 2006 vs. year 2002), the total biomass decreased by $50 \%$ in reach 1 and $59 \%$ in reach 2 , the brown trout biomass decreased by $53 \%$ in reach 1 and $42 \%$ in reach 2 . The European grayling biomass decreased by $81 \%$ in reach 1 and $72 \%$ in reach 2 . The bullhead biomass increased by $2.5 \%$ in reach 1 and decreased by $19 \%$ in reach 2 . The stone loach biomass increased by $16 \%$ in reach 1 and decreased by $21 \%$ in reach 2 . As a corollary, the proportion of occurrence of each species in the population changed in both reaches.
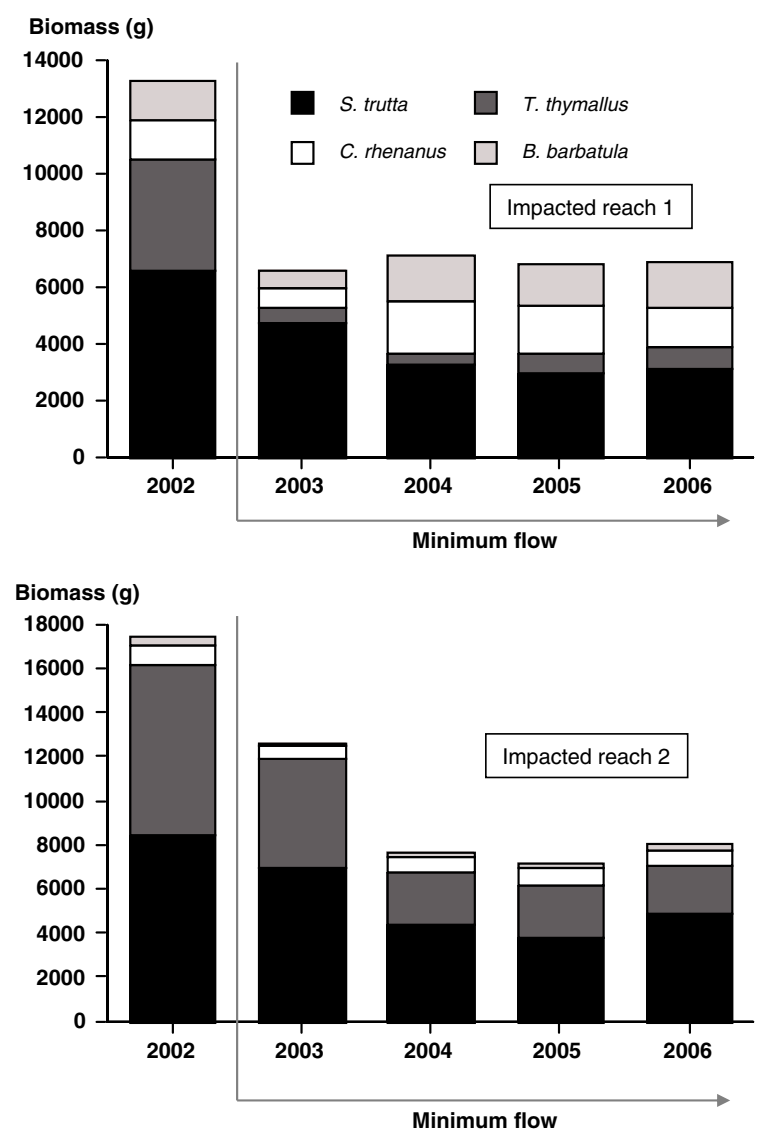

Fig. 4 Changes in the observed fish community biomass of the four representative species of the Lhomme in the impacted study reaches 1 and 2 from 2002 (natural flow conditions) to 2003, 2004, 2005 and 2006 (minimum flow conditions)

From 2004 to 2006, the global biomass of fish (brown trout, European grayling, bullhead and stone loach) captured in the natural section of the Lhomme was on average $73.6 \%$ higher ( $\mathrm{SE} \pm 18.2$ ) than in the impacted study reaches 1 and 2 during the same year.

\section{Changes in biomass by unit of wetted area (B/WA)}

Modification of biomass by unit of wetted area differed for reaches 1 and 2. In 2003, the B/WA mainly decreased for the European grayling in reach $1(-82 \%)$ and to a lesser extend in reach $2(-23 \%)$, but the $\mathrm{B} / \mathrm{WA}$ of the brown trout did not change a great deal (7.8\% for reach 1 and $0 \%$ for reach 2$)$. In spring 2004, the B/WA still decreased substantially for the European grayling and started decreasing for the brown trout at the same intensity in both reaches 
$(-36 \%)$. The B/WA of the bullhead and the stone loach largely increased in both reaches in comparison with the initial situation of 2002 (e.g. $+66 \%$ in reach 1 and $+56 \%$ in reach 2 for the bullhead). In 2005 and 2006, changes were more limited and the values of B/ WA remained close to the 2004 values. In comparison with the initial situation (year 2006 versus year 2002), the B/WA of the brown trout decreased by $39 \%$ in reach 1 and $30 \%$ in reach 2 ; the B/WA of the European grayling decreased by $85 \%$ in reach 1 and $66 \%$ in reach 2 . On the contrary, the B/WA increased by $32 \%$ in reach 1 and $48 \%$ in reach 2 . In the stone loach, the B/WA increased by $50 \%$ in reach 1 but decreased by $4 \%$ in reach 2 .

\section{Changes in fish size composition}

Before the HPP began operating, the distribution by length classes of the European grayling (sum of fish captured in both impacted reaches) was bimodal, with a dominance of classes $1^{+}$and $2^{+}$(Fig. 5), impacted reaches 1 and 2 combined. From 2003 to 2004, the number of larger individuals mostly decreased. In 2005 and 2006, the distribution was highly discontinuous, with a dominance of the $1^{+}$age class. The proportion of juveniles, individuals assimilated to $0+$ and $1+$ age classes (fork length $<170 \mathrm{~mm}$ ), versus adults $(>1+$, fork length $>170 \mathrm{~mm})$ progressively inverted from 2002 to 2006. In 2002, the number of adults was by far the highest. In 2003, the number of adults started decreasing. In 2004, the ratio became almost identical, but the quantity of adults was still higher. Finally, in 2005 and 2006, the proportions reversed and the juveniles became most abundant.

Similar results were obtained for the brown trout (Fig. 6), impacted reaches 1 and 2 combined. As for the European grayling, the proportion of age classes $0+$ and $1+$ (juvenile, fork length $<150 \mathrm{~mm}$ ) versus adults $(>1+$, fork length $>150 \mathrm{~mm}$ ) varied considerably from 2002 to 2006. In 2002 and 2003, the proportion of adults was higher in the brown trout population. In 2004, the proportion gradually became nearly identical. In 2005 and 2006, the proportions were reversed and the juveniles were more abundant than the adults. In 2006, the $1+$ brown trout were more abundant than in 2002 in natural flow conditions.

In the natural reach of the Lhomme, the length class distribution of the European grayling and the brown trout was relatively constant from 2004 to 2006 and we did not observe a reduction in the proportion of adults, as was the case in the impacted reaches 1 and 2 (Fig. 7).

\section{Discussion}

The setting of a minimum flow (based on the tenth of the mean natural annual flow) in the grayling zone of the Lhomme caused substantial changes in the fish community structure of the stream.

The quantitative fish inventory carried out after the start-up of the new hydraulic power plant revealed a drastic reduction in the range of European grayling and brown trout communities in comparison with the initial situation under natural flow conditions. The process of loss of biomass of European grayling was immediate and could be highlighted during the early weeks following the setting of the minimum flow. The species was highly affected as its total biomass decreased on average by more than $76 \%$ after the 4 th year of the HPP operation. Several authors (Peterson, 1968; Dyk, 1984; Northcote, 1995; Greenberg et al., 1996) proposed that European grayling show more flexibility in their habitat selection than brown trout, as they are less attached to instream cover. Interestingly, our study suggests that this does not prevent the species from being highly vulnerable after an artificial reduction in flow in small salmonid streams. As suggested by the habitat simulation, the reduction in the European grayling biomass in the river Lhomme was caused by the near total loss of central deep run habitats (depth $>70 \mathrm{~cm}$ and mean water velocity $>40 \mathrm{~cm} \mathrm{~s}^{-1}$ ) in which the majority was captured before the setting of the minimum flow and that are known to be their preferred habitat (Blase and Philippart, unpublished; Mallet et al., 2000).

Brown trout populations were also highly altered by the minimum flow, as its biomass greatly decreased in both reaches (average loss of biomass after the 4th year of HPP operation: 48\%). However, the process of biomass loss was mainly observed during the 2nd year of operation, after the first spawning season in minimum flow conditions. Our results demonstrated that brown trout seemed better able to adapt their habitat use in the disturbed environment, as their biomass by unity of wetted area was less affected than that of the European grayling, 
Fig. 5 Left graphs: changes in the European grayling (Thymallus thymallus) size composition in impacted study reaches $1+2$ from 2002 (natural flow conditions) to 2003, 2004, 2005 and 2006 (minimum flow conditions). Right graphs: changes in the proportion of juvenile individuals $(<1+)$ and adult individuals $(>1+)$ during the same period. Number of individuals is the total captured fish number at each sampling date
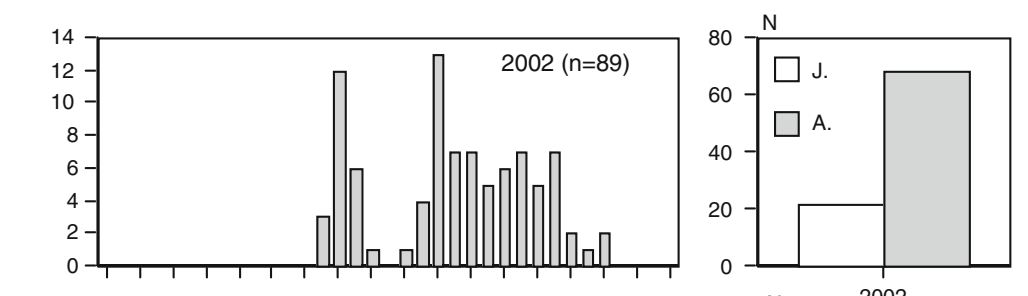

Natural flow
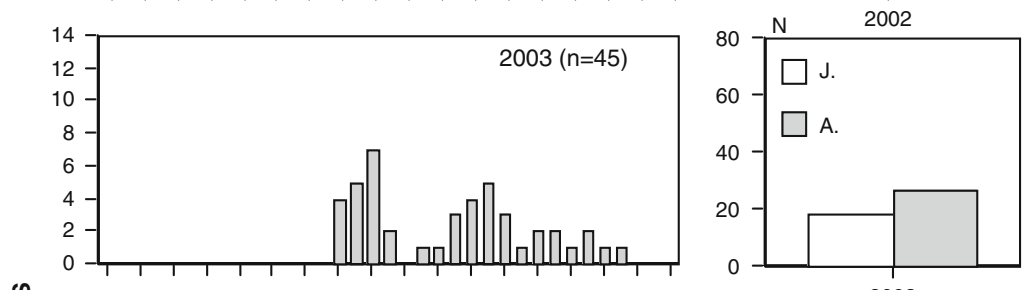

Minimum flow
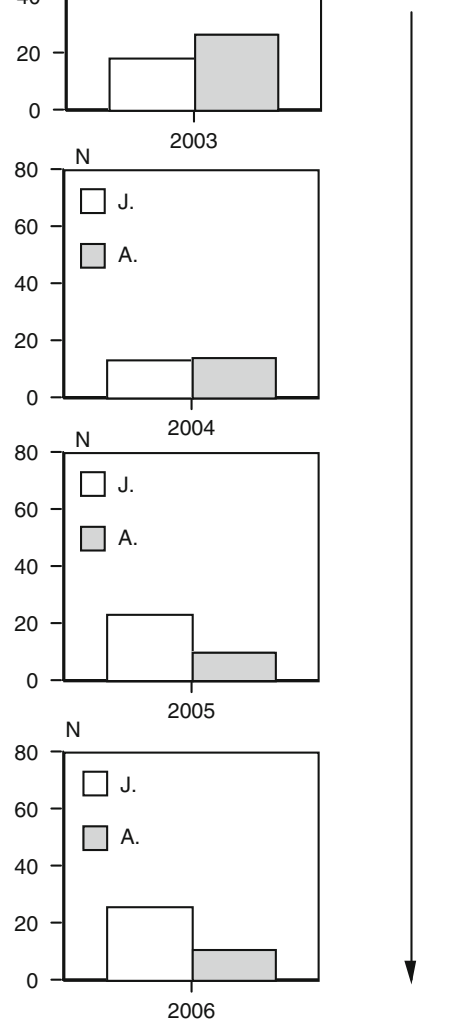

which shows a more effective use of the remaining habitat.

Past studies on the effects of minimum flow on brown trout populations in small rivers have shown contrasting outcomes. Baran et al. (1995) highlighted a reduction in biomass and densities per linear metre of stream in the French Pyrenees. In the L'Ubochnianka brook, Czech Republic (Muzik, 1995) observed $a \approx 50 \%$ decrease of brown trout biomass after one year of exploitation of a small hydroelectric power plant. On the other hand, in the French stream Roizonne (trout zone, low-temperature mountain stream in the Alps), Capra et al. (2003) observed that minimum flow was not associated with a negative effect on the brown trout population, because the main limiting factor in this mountain stream corresponded to high flow just after the emergence of fry. Such contrasted results underline that habitat availability, especially during low flows, is not always the main limiting factor for brown trout, as was demonstrated in France with the results of the Guaranteed Flow Working Group (Gouraud et al., 2004; Sabaton et al., 2004). However, our results demonstrate that this is not the case in the grayling 
Fig. 6 Left graphs: changes in the brown trout (Salmo trutta) size composition in impacted study reaches $1+2$ from 2002 (natural flow conditions) to 2003,2004 , 2005 and 2006 (minimum flow conditions). Right graphs: changes in the proportion of juvenile individuals $(<1+)$ and adult individuals $(>1+)$ during the same period
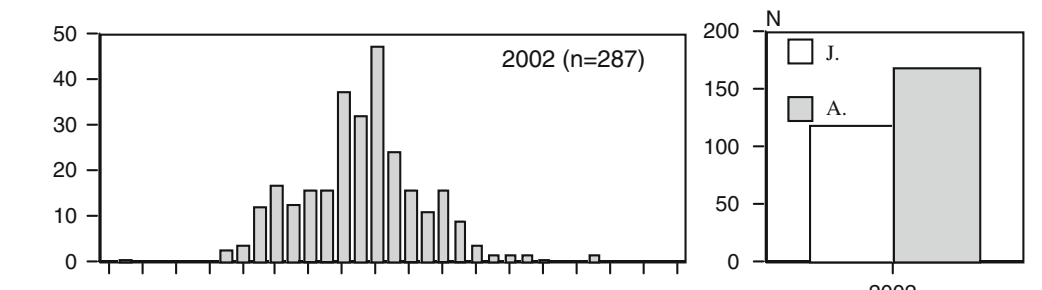

Natural flow
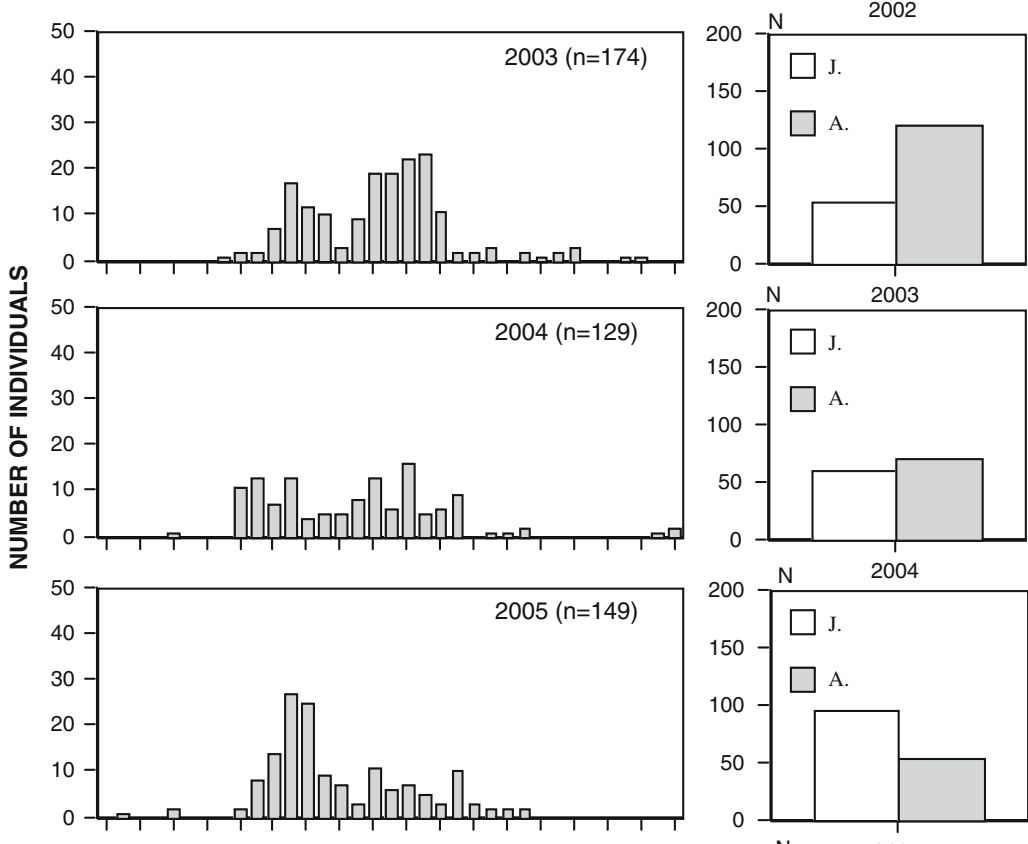

Minimum flow
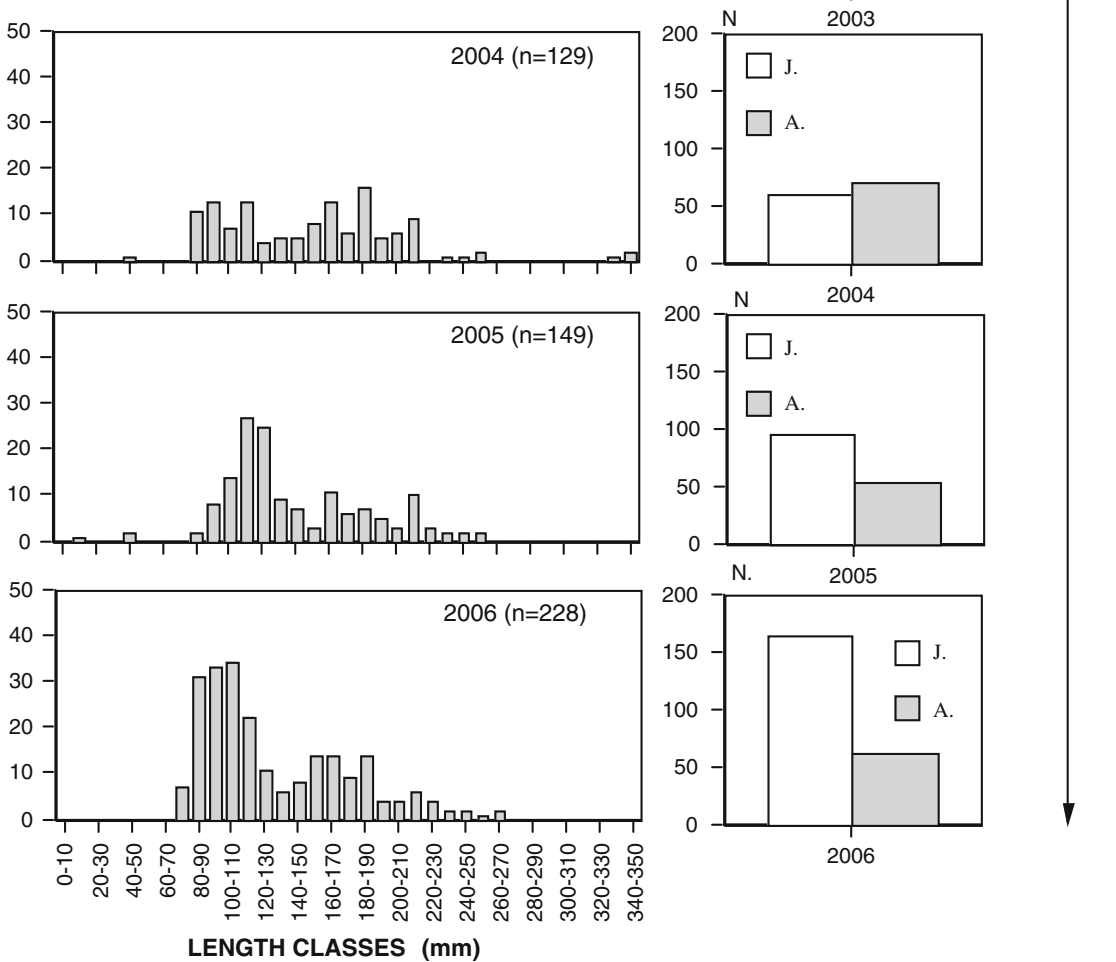

zone of salmonid steams of the Belgian Ardennes. This underscores that the same species can react differently to an artificial flow reduction, depending on the river typology and the fish population characteristics.

After the 4th year of operation, the biomass of brown trout and European grayling stopped declining and their population biomass stabilised at a low level. Whether for the brown trout or the European grayling, the biomass losses were accompanied by a progressive change in the adult versus juvenile ratio, with the juveniles finally predominating (essentially
$1+$ old) after the 3rd year of the HPP operation. This clearly demonstrated that the larger individuals (older than $1+$ ) were more affected than the smaller ones by decreasing discharge conditions and that the habitat became better suited for younger individuals. Similar observations were made by Kubečka et al. (1997) who demonstrated that water abstraction caused succession from large-bodied fish species (adult brown trout, chub, dace and grayling) towards small-bodied fish (trout fry, minnow, bullhead, stone loach and gudgeon) in different Czech rivers. Habitat modelling corroborates this hypothesis in that the 
Fig. 7 Changes in the brown trout (Salmo trutta) and European grayling size composition from 2004 to 2006 in the reference site in natural flow conditions

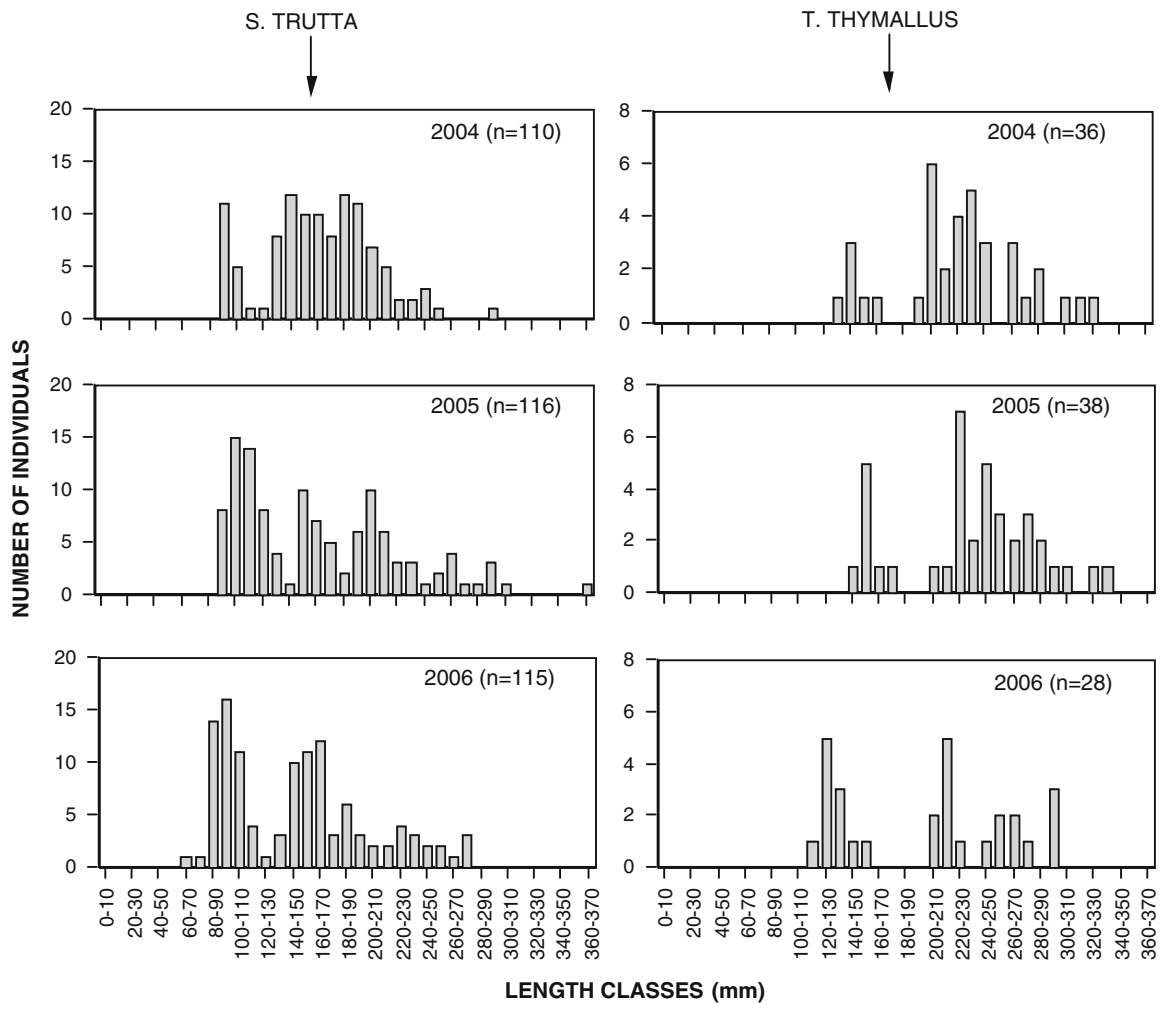

curves for trends in WUA as a function of discharge clearly demonstrate poorer habitat suitability for adult brown trout and European grayling during minimum flow conditions. Even if the efficiency of removal by electrocfishing is less appropriate for small-bodied species, it appears that the decrease in brown trout and European grayling populations was not associated with a similar decline in the biomass of the target small-bodied species (stone loach and bullhead). Their total biomass slightly increased in reach 1 and decreased in reach 2. However, the biomass by unit of wetted area of the bullhead largely increased in both reaches and the biomass by unit of wetted area of the stone loach essentially increased in the shallower reach 1 . This better availability (in terms of WUA) of habitats by wetted area for bullhead and stone loach in minimum flow conditions in comparison with those of brown trout and European grayling was also suggested by habitat modelling. Nonetheless, the models do not integrate the biological interactions between the species; the increase in bullhead and stone loach biomass may also be partially explained by a decrease in brown trout predation on these species. Similar relations between the abundance of brown trout and bullhead were already observed in another stream of the Belgian Ardennes by Philippart (1979). The reactions of the non-target fish species were impossible to estimate, as their abundance in the study site is very limited.

All changes in biomass and community structure observed in the Lhomme are quite severe and can not only be related to the variations in the natural recruitment of the river's fish community, as was confirmed by the inventories carried out during three consecutive years in a reference site in natural flow conditions. Furthermore, scrupulous analysis of the outcomes of annual removal by electrofishing in a similar river of the Belgian Ardennes from 1978 to 2006 (the Aisne, with the same fish population; Philippart, unpublished results) revealed that such large losses of biomass or major changes in community structure or size composition have never been observed to date. As suggested by Cattanéo et al. (2003), we hypothesised that if no significant change in population dynamics occurred in close streams, nothing should occur in the Lhomme. This reinforces the statement that the changes observed in the 
Lhomme were essentially caused by the setting of the minimum flow and by the consecutive loss of the quality and the availability of habitat.

In conclusion, this study demonstrated that the setting of a minimum flow based on the tenth of the mean annual flow in the grayling zone of a small gravel bed stream cannot be considered as satisfactory to maintain the integrity of the fish community structure in the bypassed reaches studied. Furthermore, the effects on the fish population structure are added to the problems involving fish movements in the same study site (Ovidio et al., 2004). The population response observed in this study would have been partially predictable by habitat modelling before the start-up of the HPP and a more reasonable proposal of minimum flow would have been proposed as suggested by Lamouroux et al. (2006). Indeed, in the river Rhône (France), they demonstrated that an increase in the relative abundance of species preferring fast-flowing microhabitats after a minimum flow increase was well predicted using habitat models. Considering the extreme vulnerability of the European grayling and the fragility of the natural brown trout population, we strongly suggest that any proposals for new HPP installations have to be evaluated with the greatest care in their distribution area.

Acknowledgments This project was financially supported by the Ministry of Walloon Region-DGRNE-Water DivisionUnnavigable watercourses (represented by F. Lambot and P. Orban) and by a bilateral collaboration project (Tournesol project) between the University of Liège (financed by the CGRI) and the Cemagef of Lyon (financed by Direction de la Cooperation Scientifique et Universitaire). The manuscript was mainly written during a post-doctoral research stay of Michaël Ovidio in the Quantitative Hydroecology Laboratory of Lyon, which was financed by the Cemagref (financial support of SREI for reception of foreign researchers). J.C. Philippart is a research associate of the Belgian FNRS. The authors wish to thank Yvan Neus, Gilles Rimbaud (ULg) and Pascal Roger (Cemagref) for field habitat measures as well as the Walloon Fisheries Service and the Ministry of Walloon Region-Water Division for electric fishing surveys. We also thank the HPP owners and M. Champagne (local organisation of fishermen) for their kind collaboration. Anonymous reviewers provided helpful comments.

\section{References}

Acreman, M. \& M. J. Dunbar, 2004. Defining environmental river flow requirements- a review. Hydrology and Earth System Sciences 8: 861-876.
Baran, P., M. Delacoste, F. Dauba, J. M. Lascaux, A. Belaud \& S. Lek, 1995. Effects of reduced flows on brown trout (Salmo trutta L.) populations downstream dams in French Pyrenées. Regulated Rivers 10: 347-361.

Belaud, A., P. Chaveroche, P. Lim, \& C. Sabaton, 1989. Probability-of-use curves applied to brown trout (Salmo trutta fario L.) in rivers of southern France. Regulated Rivers 3: 321-336.

Bern Convention, 1979. Convention on the conservation of European wildlife and natural habitats, Bern/Berne, Council of Europe, 19/09/1974.

Bovee, K. D., 1978 Probability of Use Criteria for the Family Salmonidae. Instream Flow Information Paper No. 4, FWS/OBS 78/07, U.S. Fish and Wildlife Service, Office of Biological Services, Washington, DC 80 p.

Bovee, K. D., 1982. A Guide to Stream Habitat Analysis Using the Instream Flow Incremental Methodology. FWS/OBS 82/26. US Fish and Wildlife Service: Fort Collins, USA.

Capra, H., C. Sabaton, V. Gouraud, Y. Souchon \& P. Lim, 2003. A population dynamic model and habitat simulation as a tool to predict brown trout demography in natural and bypassed stream reaches. River Research and Applications 19: 551-568.

Cattanéo, F., B. Hugueny \& N. Lamouroux, 2003. Synchrony in brown trout, Salmo trutta, population dynamics: a 'Moran effect' on early-life stages. Oikos 100(1): 43-54.

Dyk, V., 1984. The characteristics of grayling biotopes. Acta Veterinaria Brno 53:71-80.

EIFAC, 2006. European Inland Fisheries Advisory Commission. Summary recommendations of the EIFAC Symposium on Hydropower, Flood Control and Water Abstraction. Mondsee, Austria, 14-21 June 2006. .

EU Water Framework Directive. 2000. Directive 2000/60/EC of the European Parliament and of the Council establishing a framework for the Community action in the field of water policy.

Freyhof, J., M. Kottelat \& A. Nolte, 2005. Taxonomic diversity of European Cottus with description of eight new species (Teleostei: Cottidae). Ichthyiological Exploration of Freshwaters 16: 107-172.

Gibbins, C. N. \& J. Heslop, 1998. An evaluation of inter-basin water transfers as a mechanism for augmenting salmonid and grayling habitat in the River Wear. North-East England Regulated Rivers-Research and Management 14: 357-382.

Ginot, V., Y. Souchon, H. Capra, P. Breil \& S. Valentin, 1998. Logiciel EVHA 2.0. Evaluation de l'habitat physique des poissons en rivière: Guide méthodologique. Cemagref BEA/LHQ et Ministère de l'Aménagement du Territoire et de l'Environnement.

Gouraud, V., J.-L. Baglinière, P. Baran, C. Sabaton, P. Lim \& D. Ombredane, 2001. Factors regulating brown trout populations in two French rivers: application of a dynamic population model. Regulated Rivers 17: 557-569.

Gouraud, V., P. Baran, P. Lim \& C. Sabaton, 1999. Dynamics of a population of brown trout (Salmo trutta) and fluctuations in physical habitat conditions-experiments on a stream in the Pyrenees; first results. In Cowx, IG (ed.), Rivers Fisheries. Fishing News Books. Blackwell Science, Oxford: 126-142. 
Gouraud, V., C. Sabaton \& H. Capra, 2004. Role of habitat variability in trout population dynamics: application of a dynamic population model to three French rivers. Hydroécologie Appliquée 14: 221-244.

Greenberg, L., P. Svendsen \& A. Harby, 1996. Availability of microhabitats and their use by brown trout (Salmo trutta) and grayling (Thymallus thymallus) in the River Vojmån, Sweden. Regulated Rivers 12: 287-303.

Huet, M., 1949. Aperçu de la relation entre la pente et les populations piscicoles des eaux courantes. Swiss Journal of Hydrology 11: 332-351.

Kubečka, J., J. Matěna \& P. Hartvich, 1997. Adverse ecological effects of small hydropower stations in the Czech Republic: 1. Bypass plants. Regulated Rivers: Research and Management 13: 101-113.

Lamouroux, N., H. Capra, M. Pouilly \& Y. Souchon, 1999. Fish habitat preferences in large streams of southern France. Freshwater Biology 42: 673-687.

Lamouroux, N., J.-M. Olivier, H. Capra, M. Zylberblat, A. Chandesris \& P. Roger, 2006. Fish community changes after minimum flow increase: testing quantitative predictions in the Rhône River at Pierre-Bénite, France. Freshwater Biology 51: 1730-1743.

Limerinos, J. T., 1970. Determination of the Manning coefficient from measured bedroughness in natural channels. U.S. Geol. Survey Water Supply paper 1898B, 47 p.

Mallet, J. P., N. Lamouroux, P. Sagnes \& H. Persat, 2000: Habitat preferences of European grayling and brown trout in a medium size stream, the Ain river, France. Journal of Fish Biology 56: 1312-1326.

Muzik, V., 1995. The effect of small hydroelectric power-plant on ichthyofauna of the Lubochinanka brook. Zivocisna Vyroba 40: 221-226.

Norris, R. H. \& M. C. Thoms, 1999. What is the river health? Freshwater Biology 41: 197-209.

Northcote, T. G., 1995. Comparative biology and management of Arctic and European grayling (Salmonidae, Thymallus). Reviews in Fish Biology and Fisheries 5: 141-194.

Ovidio, M., F. Paquer, H. Capra, F. Lambot, P. Gerard, E. Dupont \& J.-C. Philippart, 2004. Effects of a micro hydroelectric power plant upon population abundance, mobility and reproduction behaviour of European grayling T. thymallus and brown trout $S$. trutta in a salmonid river. In Garcia de Jalon Lastra, D. \& P. Vizcaino Martinez (eds), Proceedings of the Fifth International Symposium on Ecohydraulics, Aquatic Habitats: Analysis and Restoration Madrid, Spain: 56-62.

Paller, M. H., 1997. Recovery of a reservoir fish community from drawdown related impacts. North American Journal of Fisheries Management 17: 726-733.

Peterson, H. H., 1968. The grayling, Thymallus thymallus (L.), of the Sundsvall Bay Area. Report Institute of Freshwater Research Drottningholm 48: 36-56.

Pouilly, M., S. Valentin, H. Capra, V. Ginot \& Y. Souchon, 1995. Note technique: méthode des microhabitats, principes et protocoles d'application. Bulletin Français de la Pêche et de la Pisciculture 336: 41-54.

Philippart, J. C., 1979. Etude des populations de poissons dans les trois ruisseaux oligotrophes du basin de la Roer supérieure (Belgique). Bulletin de la Société Royale des Sciences de Liège 5-8: 212-217.

Philippart, J.-C. \& M. Vranken, 1983. Atlas des Poissons de Wallonie, distribution, écologie, éthologie, pêche, conservation. Cahiers Ethologie Appliquée 3: 395 pp.

Rogers, M. H., M. S. Allen \& D. Jones, 2005. Relationship between river surface level and fish assemblage in the Ocklawaha River, Florida. River Research and Applications 21: 501-511.

Sabaton, C., S. Valentin \& Y. Souchon, 1995. La méthode des microhabitats. Protocoles d'application. HE-31/95/10. EDF-DER/Cemagref.

Sabaton, C., Y. Souchon, J.-M. Lascaux, F. Vandewalle, P. Baran, D. Baril, H. Capra, V. Gouraud, F. Lauters, P. Lim, G. Merle \& G. Paty, 2004. The "Guaranteed Flow Working Group": a French evaluation of microhabitat component. Hydroécologie Appliquée 14: 245-270.

Santos, J. M., M. T. Ferreira, A. N. Pinheiro \& J. H. Bochechas, 2006. Effects of small hydropower plants on fish assemblage in medium-sized streams in central and northern Portugal. Aquatic Conservation: Marine and Freshwater ecosystems 16: 373-388.

Souchon, Y., F. Trocherie, E. Fragnoud \& C. Lacombe, 1989. Les modèles numériques des microhabitats des poissons: application et nouveaux développements. Revue des Sciences de l'Eau 2: 807-830.

VandenBossche, J. P., 2005. Evolution de la qualité biologique des cours d'eau de Wallonie de 1990 à 2002. Carte, poster. Centre de Recherches de la Nature, des Forêts et du bois, DGRNE-MRW, B-5030 Gembloux. 